\title{
The Effect of Job Autonomy on Psychological Well-Being: The Mediating Role of Personal Initiative
}

\author{
Feifei Yang, Yue Zhao* \\ School of Management, Shanghai University, Shanghai, China \\ Email: *zhaoyue1995@shu.edu.cn
}

How to cite this paper: Yang, F.F. and Zhao, Y. (2018) The Effect of Job Autonomy on Psychological Well-Being: The Mediating Role of Personal Initiative. Open Journal of Social Sciences, 6, 234-248. https://doi.org/10.4236/jss.2018.611017

Received: October 23, 2018

Accepted: November 20, 2018

Published: November 23, 2018

Copyright $\odot 2018$ by authors and Scientific Research Publishing Inc. This work is licensed under the Creative Commons Attribution International License (CC BY 4.0).

http://creativecommons.org/licenses/by/4.0/

\section{(c) (i) Open Access}

\begin{abstract}
Employees' psychological well-being is an important factor affecting organizational performance. Thus, through empirical study, the present article investigates the influence of employees' job autonomy on their psychological well-being. Specifically, personal initiative will mediate this relationship. To examine a series of hypotheses we developed, online survey was used to collect data. Finally, 380 respondents were accepted. Empirical data showed that employees' job autonomy is positively related to psychological well-being. Namely, the psychological well-being of employees will gain dramatic improvement when they possess high job autonomy. In addition, through the way of path analysis, we revealed that personal initiative plays a role of intermediary mechanism in the relationship between job autonomy and psychological well-being. In last part, we discussed the contribution, limitations, and the directions of future research.
\end{abstract}

\section{Keywords}

Job Autonomy, Personal Initiative, Psychological Well-Being

\section{Introduction}

Most of the fatigue we feel is caused by psychological factors, which caused by purely physical factors is actually very rare, said by Carnegie (2010), a famous American psychologist and human relations scholar [1], which reveals the importance of psychological experience. In addition, a wealth of prior research has demonstrated that employees' psychological well-being will bring numerous desirable outcomes, and personal initiative is one of them [2] [3]. Meanwhile, job autonomy, is not only a consideration of employees when choosing their career, 
but also deeply concerned by scholars [4] [5]. Based on this, we infer that job autonomy could serve as a determinant of employees' psychological well-being.

Through reviewing the literature, we are aware that the influence mechanism of job autonomy to psychological well-being has always been focused by researchers [6] [7] [8]. Further, these literatures can be grouped into two broad categories; one directly demonstrates the relationship between job autonomy and psychological well-being, and another indirectly. For example, by analyzing 3504 data with hierarchical regression, Thompson and Prottas (2006) found that job autonomy is associated with employees' well-being [5], and perceived control mediated their relationship. In addition, across-ethnic research conducted by Sheldon, Kasser, Houser-Marko, Jones, and Turban (2005) has shown that whether it is Americans or Singaporeans, and whether it is older or younger, job autonomy is always associated with higher psychological well-being [9]. Actually, over the past decades, broad literature on job autonomy and psychological well-being draw fairly consistently conclusion, namely, job autonomy is an important way to obtain high psychological well-being [10] [11].

Undeniably, great knowledge on job autonomy and psychological well-being has been accumulated [5] [9]. However, several research issues remain further investigation. For example, compared to most of previous studies which focused on the mediating role of employees' perceived control [5], there is almost no study has examined the role of personal initiative. The research gap is noteworthy, because a wealth of empirical evidence showed that employees' initiatives is associated with job autonomy [12] [13], which, in turn, will bring positive feelings [14]. Thus, the present study will from a new perspective that is personal initiative, to shed light on the relationship.

To address such research gaps, we develop a model integrating job autonomy and personal initiative to predict employees' psychological well-being. In the study, we support that employees' job autonomy in current work is a critical factor to bring their psychological well-being [9]. However, personal initiative is both associated with job autonomy and psychological well-being. Thus, we further argue the mediating effect of personal initiative on the relationship of job autonomy and psychological well-being, which refers to employees' discretionary behaviors with the intent to impact other people or environment [15]. In the process of reasoning, different theories, such as cognitive evaluation theory, job design theory, and hierarchy of needs theory are used. To test and verify our model, first step, we translated all English questionnaire items into Chinese to simplify respondents reading and understanding. Then, we put the scale on the website, and after removing unqualified responses, we finally gained 380 responses. After data analysis, we found that as we propose before, personal initiative plays a intermediary role in effecting the relationship of job autonomy and psychological well-being. Thus, job autonomy can either directly affect psychological well-being or indirectly affect through personal initiative.

The research structure of present study is as follows. First, we combed and consolidated the previous literature (i.e. search terms includes job autonomy, 
autonomy personal initiative, initiative, and psychological well-being) with questions. Based on the work done above, we made a series of hypotheses. Next step, to examine our hypotheses, we introduced a variety of methods to analyze the data, and results show that most of the hypotheses are supported. In the last part, we discussed the implications, limitation, and future research directions of present article through the way of dialogue with existing literature.

\section{Literature Review}

\subsection{Job Autonomy and Psychological Well-Being}

Job autonomy reflects the degree of freedom and independence of employees when handling their regular works [16]. Explicitly, employees, who retain high job autonomy, will enjoy more opportunities to finish their work in the way they like (e.g. the timing, method, or procedures) [17].

Through 5-day diary survey of 95 employees, Petrou and colleagues (2012) found that job autonomy has a positive effect on shaping employees' psychological well-being [11]. In fact, according to Deci and Ryan (1985), cognitive evaluation theory shows that the employees' intrinsic motivation can be effected by external forces (e.g. job autonomy) [18]. Yet job autonomy, which is a significant external force, born with a signal of focal employee. In means that employees, who enjoy high job autonomy, are trusted by the organization [11] [19]. In turn, the feeling of being trusted will promote employees' psychological well-being.

Besides, employees with higher job autonomy will be relatively free to handle their work. It means that there is unnecessary to report some decisions to their superiors. As a result, they can cope effectively with job tasks. Less constraints can enhance employees' positive emotions at work. Thus, the psychological satisfaction of those employees will be high [10]. The premise is supported by a wealth of empirical evidence, offered by Sheldon, Kasser, Houser-Marko, Jones, and Turban (2005), that job autonomy is associated with higher psychological well-being [9]. On the basis of these considerations we hypothesize that:

Hypothesis 1: Job autonomy will be positively related to personal well-being.

\subsection{Job Autonomy and Personal Initiative}

Accompanied by the active roles of employee initiatives play are found, in recent years, there is a growing number of research on the predictors of personal initiative [17] [20] [21] [22]. In the present study, personal initiative refers to employees' discretionary behaviors with the intent to impact themselves or their environments. In general, personal initiative includes suggestive behavior, help behavior, actively undertake work-related issues,collaborating, and so forth [13] [23].

In a large body of literature on job autonomy and personal initiative, Grant and Ashford (2008) suggest that job characteristics are important contextual predictors of employees' initiatives [13], which aligns with previous findings showed by Morgeson, Delaney-Klinger, and Hemingway (2005) [24]. And job autonomy is one of the most important characteristics. Because personal initia- 
tive involves risk, if there is not enough job autonomy for employees, that is, they may suffer a predicament after taking initiatives [25], which make they perceive incompetent. Thus, they may stop trying to make things happen [12]. Instead, those employees, who have more job autonomy, will gain psychological safety to take initiatives.

In addition to high psychological safety, the effect of job autonomy on personal initiative is twofold. On the one hand, according to the classical job design theory [16], employees' psychological states are proximal predictors of their behaviors. Specifically, there is a consensus that rights and obligations are equal. Intangibly, employees will hold that they should take more initiatives behaviors as they enjoy high job autonomy. Thus, felt responsibility will push employees to take initiatives [13] [15]. On the hand, according to Tims and Bakker (2010), the role-breadth self-efficacy of employees have tremendously increased in high job autonomy [26]. Namely, it's easier for employees to take on broader roles when they possesses more job autonomy [27]. As a result, there will generate a lager number of initiatives. Collectively, we hypothesize that:

Hypothesis 2: Job autonomy will be positively related to personal initiative.

\subsection{Personal Initiative and Psychological Well-Being}

Psychological well-being, which reflects employee's psychological satisfaction with their current job, has attracted wide attention of employees and scholars [28] [29]. Nonetheless, so far, little research has explicitly verified the relationship between personal initiative and psychological well-being.

Based on the integration of seniors' academic crystallization, Bindl and Parker (2010) suggested that positive feelings will follow the initiatives [14]. Explicitly, in the process of effecting psychological well-being, personal initiatives play two significant but distinctive roles: reduce the tedium of work and increase employees' self-efficacy. On the one hand, by taking initiatives, employees perceive their jobs more meaningful and significant. Yet through analyzing of 272 data collected over 18 months, Staw, Sutton, and Pelled (1994) showed that these positive feelings play a role of promoter in shaping high psychological well-being [30]. On the other hand, through taking initiative, employees may find a lot of potential and hidden value of themselves, which, in turn, enhance their self-efficacy [31]. Namely, employees will convinced that they behaviors will have an impact on the organization (e.g. people and environment) [17] [21], [32], and themselves are not trivia. Thus, the combination of both roles will strengthen the influence of personal initiative on psychological well-being. As noted earlier in this paper, we predict the following:

Hypothesis 3: Personal initiative will be positively related to psychological well-being.

\subsection{Mediating Role of Personal Initiative}

Although prior research has examined the effect of job autonomy on psychological well-being, the intermediary mechanism underlying this process has not 
been thoroughly explored. In this article, we introduced personal initiative, which served as intermediary, to further explore its impact on job autonomy and psychological well-being. Based on hierarchy of needs theory, offered by Maslow (1954), that there are five categories of needs existing in human development [33]. However, for employees, self-actualization is their ultimate goal.

As outlined above, with the addition of job autonomy, the probability of employees to take initiatives, which in order to influence their surroundings, gain dramatic improvement. Yet through initiative behaviors, employees will perceive not only the valuable and significant of themselves roles, but also the interesting and meaningful of their current jobs [21] [30]. Intangibly, employees will hold a recognition that their self-value get realized. It is noteworthy that such positive feeling (e.g. self-value get realized) is an important determinant of high psychological well-being. However, the situation is completely different as employees' job autonomy is low. Employees, who just have little job autonomy, may tend to do their own affairs, rather than play extra-roles [23] [34]. As a result, repeated work may make employees be difficult to perceive the value of current job, which will bring them lower psychological satisfaction. Thus, we argue that:

Hypothesis 4: Personal initiative will mediate the relationship of job autonomy and psychological well-being.

\section{Research Methods}

\subsection{Research Design}

In this study, online survey is used to collect data, which is an effective and widely used method [35]. First of all, we posted the questionnaire on the websites. Simultaneously, in the home page of our questionnaire, we made a commitment that the data is only used for academic research and do not reveal their personal privacy. All respondents are job incumbents when they are surveyed, and they are voluntarily involved in the investigation activities. Finally, after excluding invalid and incomplete data, we gained the samples of 380 respondents. The original English questionnaire items are shown in the Appendix.

Table 1 reflects the demographic characteristics of the data which we used in this paper.

\subsection{Measurement}

To reduce the reading difficulty of respondents, we translated all English questionnaire items into Chinese. Meanwhile, we abide by the back-translation procedures [36] strictly to ensure the rigour and accuracy of translations. As a result, these items were designed in the form of 7-point Likert scales, and respondents are required to rate the Chinese items, rating from $1=$ strongly disagree to 7 = strongly agree.

Job autonomy. We adapted Frese, Kring, Soose, and Zempel's (1996) scale to measure respondents' job autonomy [19]. The scale contains four items that describe the extent to which participants are controlled at work. One sample item 
Table 1. Demographic characteristics of the analytic sample.

\begin{tabular}{|c|c|c|c|}
\hline \multicolumn{2}{|c|}{ Demographic Characteristics } & \multirow{2}{*}{$\begin{array}{c}\text { Unweighted n's } \\
254\end{array}$} & \multirow{2}{*}{$\begin{array}{c}\text { Weighted Percentages } \\
66.84\end{array}$} \\
\hline & Male & & \\
\hline Genduet & Female & 126 & 33.16 \\
\hline \multirow{4}{*}{ Age } & $\leq 18$ & 1 & 0.26 \\
\hline & $19-29$ & 195 & 51.32 \\
\hline & $30-39$ & 134 & 35.26 \\
\hline & $\geq 40$ & 50 & 13.16 \\
\hline \multirow{5}{*}{ Education } & middle school and below & 8 & 2.11 \\
\hline & high school & 27 & 7.11 \\
\hline & associate degree & 143 & 37.63 \\
\hline & bachelor's degree & 135 & 35.53 \\
\hline & master's degree or above & 67 & 17.63 \\
\hline \multirow{5}{*}{ Tenure } & $\leq 1$ & 126 & 33.16 \\
\hline & $2-3$ & 84 & 22.11 \\
\hline & $4-5$ & 53 & 13.95 \\
\hline & $6-9$ & 41 & 10.79 \\
\hline & $\geq 10$ & 78 & 20.53 \\
\hline
\end{tabular}

was "I can determine how do my work." The Cronbach's alpha coefficient of the scale was 0.87 .

Personal initiative. We used the scale, which offered by Frese, Fay, Leng, Hilburger, and Tag's (1997), to assess personal initiative [37]. There are seven items in the scale, for example "I take initiative immediately even when others don' $t$ " and "Whenever something goes wrong, I search for a solution immediately". The Cronbach's alpha coefficient of the scale was 0.91 .

Psychological well-being. We employed Brunetto and colleagues' (2011) scale to measure psychological well-being of participants [28]. The scale, which regularly used to investigate employees' satisfaction with current job, includes four items, such as "Overall I think I am reasonably satisfied with my work life" and "Overall, I get enough time to reflect on what I do at work". The Cronbach's alpha coefficient of the scale was 0.88 .

Control variables. In the present study, we developed four control variables in order to minimize the interference of exogenous variables, including participants' age, gender, education, and organization tenure. Specific measurement scales can be seen in Table 2 .

\section{Results}

\subsection{Factor Analyses}

Considering the problem that there are too many items, in the first step, refer to the process which offered by Kishton and Widaman (1994), we packaged the 
Table 2. Variables and the scale.

\begin{tabular}{ccc}
\hline Variables & Scale & Cronbach's alpha coefficient \\
\hline Job autonomy & Frese, Kring, Soose, and Zempel's (1996) & 0.87 \\
Personal initiative & $\begin{array}{c}\text { Frese, Fay, Leng, } \\
\text { Hilburger, and Tag's (1997) }\end{array}$ & 0.91 \\
Psychological well-being & Brunetto and colleagues' (2011) & 0.88 \\
\hline
\end{tabular}

same category items and extracted three mainly indicators [38]. Next, we employed the method of confirmatory factor analyses (CFAs) through the package "lavaan" [39] in the R environment [40] to evaluate the coefficient of our three-factor model.

To ensure the rigor of the data analysis, we strictly abide by the procedures offered by Aguinis, Gottfredson, and Culpepper (2013) [41]. First, we develop a null model $\left(\mathrm{M}_{0}\right)$ with not any predictors but psychological well-being, we selected 3-factor model $\left(\mathrm{M}_{1}\right)$ as baseline due to it is parsimonious, two 2-factor models $\left(M_{2}\right.$ and $\left.M_{3}\right)$, and finally model shows that three constructs represent a single dimension $\left(\mathrm{M}_{4}\right)$. Specific measurement results of variance analyses can be seen in Table 3.

Obviously, as Table 3 shown, compared with other models, the index of three-factor baseline model, namely $\mathrm{M}_{1}$, is more perfect $\left(\chi^{2}(87)=375.46, p<\right.$ 0.001 ; $\mathrm{CFI}=0.92$; NNFI $=0.91$; RMSEA $=0.09$ ). It means that the three constructs can be distinguished well.

\subsection{Hypothesis Testing}

Table 4 reflects the means, standard deviations, as well as correlation coefficients among independent, dependent, and control variables.

The analysis results showed that high job autonomy, align with our predictions, will generate a positive effect on employee' psychological well-being ( $r=$ $0.65, p<0.001)$. In addition, there also exists positive relationship between job autonomy and personal initiative $(r=0.56, p<0.001)$, personal initiative and psychological well-beings $(r=0.55, p<0.001)$. It means that Hypotheses 1,2 , and 3 are preliminary supported.

To further test and verify the intermediary role of personal initiative, we applied the boot-strapping approach to examine its significance again. Results (see Table 5) showed that in 95\% confidence intervals, the coefficient between job autonomy and psychological well-being was significant $(\beta=0.48, p<0.001)$, that is, Hypothesis 1 was supported. Similarly, we also calculated the coefficients between both job autonomy and personal initiative $(\beta=0.44, p<0.001)$ and personal initiative and psychological well-being $(\beta=0.35, p<0.001)$, they were all significant. Therefore, Hypotheses 2 and 3 were also verified. Naturally, Hypothesis 4 was supported. Namely, personal initiative mediates the relationship between job autonomy and psychological well-being. Considering that the coefficient between job autonomy and psychological well-being was significant 
Table 3. Results of multilevel modeling analyses.

\begin{tabular}{ccccccc}
\hline Model Specifications & $\chi^{2}$ & $d f$ & $\Delta \chi^{2}$ & CFI & NNFI & RMSEA \\
\hline Null model $\left(\mathrm{M}_{0}\right)$ & 3828.59 & 105 & - & - & - & - \\
Baseline 3-factor model $\left(\mathrm{M}_{1}\right)$ & 375.46 & 87 & - & 0.92 & 0.91 & 0.09 \\
$\begin{array}{c}\text { Job autonomy and Personal } \\
\text { initiative combined }\left(\mathrm{M}_{2}\right)\end{array}$ & 832.96 & 89 & $457.49^{* *}$ & 0.80 & 0.76 & 0.15 \\
$\begin{array}{c}\text { Personal initiative and Psychological } \\
\text { well-being combined }\left(\mathrm{M}_{3}\right)\end{array}$ & 909.42 & 85 & $533.96^{* *}$ & 0.78 & 0.73 & 0.16 \\
$\begin{array}{c}\text { Three constructs represent } \\
\text { a single dimension }\left(\mathrm{M}_{4}\right)\end{array}$ & 1208.70 & 90 & $833.23^{* *}$ & 0.70 & 0.65 & 0.18 \\
\hline
\end{tabular}

Data sources: web survey. Notes: $N=380 . \Delta \chi^{2}$ is the change in $\chi^{2}$ compared with the baseline model. ${ }^{* *} p<$ 0.01 .

Table 4. Means, standard deviations, and correlations among study variables.

\begin{tabular}{lccccccccc}
\hline & Mean & $S D$ & 1 & 2 & 3 & 4 & 5 & 6 & 7 \\
\hline 1. JA & 4.52 & 1.35 & - & & & & & & \\
2. PI & 5.06 & 1.06 & $0.56^{* *}$ & - & & & & & \\
3. PW & 4.53 & 1.33 & $0.65^{* *}$ & $0.55^{* *}$ & - & & & & \\
4. G & 1.33 & 0.47 & 0.05 & 0.01 & 0.03 & - & & & \\
5. T & 30.7 & 7.39 & $0.16^{* *}$ & $0.12^{*}$ & $0.12^{*}$ & 0.02 & - & & \\
6. E & 4.59 & 0.93 & $0.16^{* *}$ & $0.16^{* *}$ & $0.16^{* *}$ & $-0.13^{*}$ & 0.03 & - & \\
7. A & 2.62 & 1.52 & $0.14^{* *}$ & 0.10 & $0.13^{*}$ & -0.06 & $0.70^{* *}$ & $0.13^{* *}$ & - \\
\hline
\end{tabular}

Data sources: web survey. Note: $\mathrm{JA}=\mathrm{Job}$ autonomy, PI $=$ Personal initiative, $\mathrm{PW}=$ Psychological well-being, $\mathrm{G}=$ Gender, $\mathrm{T}=$ Tenure, $\mathrm{E}=$ Education, $\mathrm{A}=$ Age. $N=380$. Gender: $1=$ male, $2=$ female. Age: 1 $=$ under 18 years old, $2=19-29$ years old, $3=30-39$ years old, $4=$ more than 40 years old. Education: $1=$ middle school and below, $2=$ high school, 3 = associate degree, $4=$ bachelor's degree, $5=$ master's degree or above. Tenure: $1=$ less than 1 year, $2=2-3$ years, $3=4-5$ years, $4=6-9$ years, $5=$ more than 10 years. ${ }^{\star} p<0.05 ;{ }^{* *} p<0.01$.

Table 5. Parameter estimates of the mediation model and $95 \%$ confidence intervals.

\begin{tabular}{ccc}
\hline & estimated effect & 95\% $\mathrm{ci}^{\mathrm{a}}$ \\
\hline Direct effects & & \\
job autonomy $\rightarrow$ psychological well-being & $0.48^{* *}$ & {$[0.387,0.564]$} \\
job autonomy $\rightarrow$ personal initiative & $0.44^{* *}$ & {$[0.373,0.504]$} \\
personal initiative $\rightarrow$ psychological well-being & $0.35^{\star *}$ & {$[0.235,0.456]$} \\
Indirect effects & & \\
job autonomy $\rightarrow$ personal initiative $\rightarrow$ psychological well-being & $0.15^{\star *}$ & {$[0.098,0.205]$} \\
\hline
\end{tabular}

Data sources: web survey. Notes: $N=380 .{ }^{\star} p<0.05 ;{ }^{\star *} p<0.01$.

$(\beta=0.48, p<0.001)$. Therefore, personal initiative will partially mediate the effect of job autonomy on psychological well-being.

As a result, Figure 1 shows the theoretical model of present study and the various coefficient between three variables. 


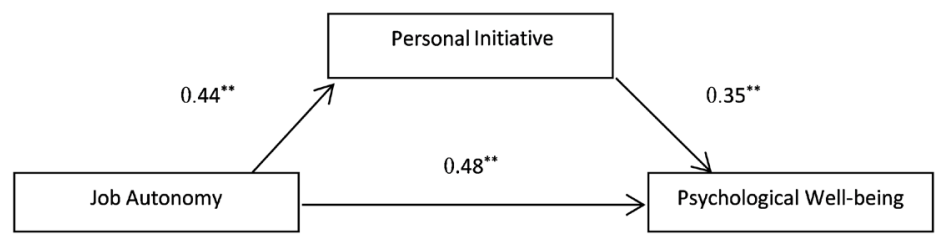

Figure 1. Standardized path coefficients and hypothesized model. Notes: $N=$ 380. ${ }^{\star} p<0.05 ;{ }^{\star *} p<0.01$.

\section{Discussion}

In the present study, a theoretical model was established to explore the influence mechanism of employees' job autonomy on their psychological well-being. Specifically, we introduced personal initiative, which act as a mediator, will influence the relationship between employees' job autonomy and psychological well-being. To verify our hypothesis, we launched an online survey in China. As expected, our hypothesis get supported by empirical results.

\subsection{Theoretical and Practical Implications}

The contributions of this article are as follows. First, our present study extend the research on psychological well-being and finds that job autonomy plays a positive role in the process of effecting psychological well-being [9]. Specifically, different from the prior studies, which may just reported the directly relationship between job autonomy and psychological well-being [11], our results indicate that job autonomy influences psychological well-being and that personal initiative plays an intermediary role. Although along with the positive sides of psychological well-being was discovered, a large number of research on how to enhance employees' psychological well-being have emerged [42], the relationship between job autonomy and psychological well-being under personal initiative' intermediary mechanism is unexplored so far. Second, empirical results show that the mediating role of personal initiative is incomplete. We find that job autonomy not only can directly affect employees' psychological well-being [9], but also can play the role through other channels (e.g., job autonomy), which points the way for future research. It means that future research can try other intermediary variables which influence the relationship between job autonomy and psychological well-being. Third, contrary to the previous studies, which focus on the effect of psychological well-being on personal initiative [2] [3], the article uses reverse logic to explore another situation, that is, the influence of personal initiative on psychological well-being. To some extent, the present study offers a deeper explore to understand the role of both sides.

Our findings also have many significant implications for practice. First, for organization, this paper verified that high job autonomy, which makes employees perceive trust from management [43] and sense of security [23], will bring high initiative behaviors. The finding is helpful to management. That is, appropriate authorization is necessary and effective way to improve employee initiative. In addition, for employees, our empirical results show that personal 
initiative will contribute to the formation of psychological well-being ( $\beta=0.35, p$ $<0.001)$. Namely, employees can improve their work experience through taking some initiative behaviors.

\subsection{Limitations and Future Research Directions}

The expecting findings from the present study also have several limitations which should take into consider. First, the data we used in this study from same source. Though we adopt both statistical and procedural ways [44] to keep reliability and validity of results, common method variances are difficult to completely avoid. Future study can try to increase the sources of data collection, such as using interviews, experiments, and other methods. Because, multiple data sources can effectively avoid the error caused by common method variances. Second, in the present study, we only test and verify one intermediary mechanism, that is personal initiative. It means that there may exist other intermediary mechanism or moderator wait to be explored. Thus, we encourage future study to explore other possible mediators to further supplement existing theories. Finally, in the present study, we control some exogenous variables, such as age, gender, education, and organization tenure. Nonetheless, due to limited energy, there are many variables which may affect the results are beyond our control. Thus, in future research, other exogenous variables (e.g., industry) will be taken into consideration.

Despite existing several limitations, this article makes some important contributions. For example, it investigates how people perceived job autonomy influence the formation of psychological well-being. Meanwhile, the present study also supplies an empirical work for future deeper research by testing and verifying the mediating effect of personal initiative. The findings also offer important implications for the managers and employees.

\section{Conclusion}

In this paper, we used 380 simple from online survey to examine our hypotheses. Through confirmatory factor analyses (CFAs) and multilevel modeling analyses, we found that job autonomy will be positively related to personal well-being. Meanwhile, Personal initiative will mediate the relationship between job autonomy and psychological well-being. These findings are helpful in the choice of management methods, that is, it is necessary to give employees appropriate autonomy, and it can bring high initiative behaviors. In the future, we encourage a further exploration about the topic.

\section{Conflicts of Interest}

The authors declare no conflicts of interest regarding the publication of this paper.

\section{References}

[1] Carnegie, D. (2010) How to Win Friends and Influence People. Simon \&Schuster. 
[2] Frey, B.S. and Stutzer, A. (2002) What Can Economists Learn from Happiness Research? Journal of Economic Literature, 40, 402-435.

https://doi.org/10.1257/jel.40.2.402

[3] Lyubomirsky, S. and Tucker, K. (1998) Implications of Individual Differences in Subjective Happiness for Perceiving, Interpreting, and Thinking about Life Events. Motivation and Emotion, 22, 155-186. https://doi.org/10.1023/A:1021396422190

[4] Ahuja, M.K., Chudoba, K.M., Kacmar, C.J., McKnight, D.H. and George, J.F. (2007) IT Road Warriors: Balancing Work-Family Conflict, Job Autonomy, and Work Overload to Mitigate Turnover Intentions. Mis Quarterly, 31, 1-17. https://doi.org/10.2307/25148778

[5] Thompson, C.A. and Prottas, D.J. (2006) Relationships among Organizational Family Support, Job Autonomy, Perceived Control, and Employee Well-Being. Journal of Occupational Health Psychology, 11, 100-118. https://doi.org/10.1037/1076-8998.10.4.100

[6] Chung-Yan, G.A. (2010) The Nonlinear Effects of Job Complexity and Autonomy on Job Satisfaction, Turnover, and Psychological Well-Being. Journal of Occupational Health Psychology, 15, 237-251. https://doi.org/10.1037/a0019823

[7] Daniels, K. and Guppy, A. (1994) Occupational Stress, Social Support, Job Control, and Psychological Well-Being. Human Relations, 47, 1523-1544.

https://doi.org/10.1177/001872679404701205

[8] Deci, E.L. and Ryan, R.M. (2008) Facilitating Optimal Motivation and Psychological Well-Being across Life's Domains. Canadian Psychology/Psychologie Canadienne, 49, 14-23. https://doi.org/10.1037/0708-5591.49.1.14

[9] Sheldon, K.M., Kasser, T., Houser-Marko, L., Jones, T. and Turban, D. (2005) Doing One's Duty: Chronological Age, Felt Autonomy, and Subjective Well-Being. European Journal of Personality, 19, 97-115. https://doi.org/10.1002/per.535

[10] Karademas, E.C. (2006) Self-Efficacy, Social Support and Well-Being: The Mediating Role of Optimism. Personality and Individual Differences, 40, 1281-1290. https://doi.org/10.1016/j.paid.2005.10.019

[11] Petrou, P., Demerouti, E., Peeters, M.C.W., Schaufeli, W.B. and Hetland, J. (2012) Crafting a Job on a Daily Basis: Contextual Correlates and the Link to Work Engagement. Journal of Organizational Behavior, 33, 1120-1141. https://doi.org/10.1002/job.1783

[12] Fay, D. and Michael, F. (2001) The Concept of Personal Initiative: An Overview of Validity Studies. Human Performance, 14, 97-124. https://doi.org/10.1207/S15327043HUP1401_06

[13] Grant, A.M. and Ashford, S.J. (2008) The Dynamics of Proactivity at Work. Research in Organizational Behavior, 28, 3-34. https://doi.org/10.1016/j.riob.2008.04.002

[14] Bindl, U.K. and Parker, S.K. (2010) Proactive Work Behavior: Forward-thinking and Change-Oriented Action in Organizations. In: Zedeck, S., Ed., APA Handbook of Industrial and Organizational Psychology, American Psychological Association, Washington DC, 567-598.

[15] Morrison, E.W. and Phelps, C.C. (1999) Taking Charge at Work: Extrarole Efforts to Initiate Workplace Change. Academy of Management Journal, 42, 403-419.

[16] Hackman, J.R. and Oldham, G.R. (1976) Motivation through the Design of Work: Test of a Theory. Organizational Behavior and Human Performance, 16, 250-279. https://doi.org/10.1016/0030-5073(76)90016-7

[17] Kulik, C.T., Oldham, G.R. and Hackman, J.R. (1987) Work Design as An Approach 
to Person-Environment Fit. Journal of Vocational Behavior, 31, 278-296. https://doi.org/10.1016/0001-8791(87)90044-3

[18] Deci, E.L. and Ryan, R.M. (1985) Intrinsic Motivation and Self-Determination in Human Behavior. Springer, Boston, MA. https://doi.org/10.1007/978-1-4899-2271-7

[19] Frese, M., Kring, W., Soose, A. and Zempel, J. (1996) Personal Initiative at Work: Differences between East and West Germany. Academy of ManagementJournal, 39, 37-63.

[20] Campbell, D.J. (2000) The Proactive Employee: Managing Workplace Initiative. Academy of Management Executive, 14, 52-66.

[21] Nicholson, N. (1984) A Theory of Work Role Transitions. Administrative Science Quarterly, 29, 172-191. https://doi.org/10.2307/2393172

[22] Van Dyne, L. and LePine, J.A. (1998) Helping and Voice Extra-Role Behaviors: Evidence of Construct and Predictive Validity. Academy of Management Journal, 41, 108-119.

[23] Van Dyne, L., Cummings, L.L. and McLean P.J. (1995) Extra-Role Behaviors: In Pursuit of Construct and Definitional Clarity (A Bridge over Muddied Waters). In: Cummings, L.L. and Staw, B.M., Eds., Research in Organizational Behavior, JAI Press, Greenwich, CT, 215-285.

[24] Morgeson, F.P., Delaney-Klinger, K. and Hemingway, M.A. (2005) The Importance of Job Autonomy, Cognitive Ability, and Job-Related Skill for Predicting Role Breadth and Job Performance. Journal of Applied Psychology, 90, 399-406. https://doi.org/10.1037/0021-9010.90.2.399

[25] Van Dyne, L., Ang, S. and Botero, I.C. (2003) Conceptualizing Employee Silence and Employee Voice as Multidimensional Constructs. Journal of Management Studies, 40, 1359-1392. https://doi.org/10.1111/1467-6486.00384

[26] Tims, M. and Bakker, A.B. (2010) Job Crafting: Towards a New Model of Individual Job Redesign. SA Journal of Industrial Psychology, 36, 1-9. https://doi.org/10.4102/sajip.v36i2.841

[27] Wrzesniewski, A. and Dutton, J.E. (2001) Crafting a Job: Revisioning Employees as Active Crafters of Their Work. Academy of Management Review, 26, 179-201. https://doi.org/10.5465/amr.2001.4378011

[28] Brunetto, Y., Farr-Wharton, R. and Shacklock, K. (2011) Supervisor-Nurse Relationships, Teamwork, Role Ambiguity and Well-Being: Public versus Private Sector Nurses. Asia Pacific Journal of Human Resources, 49, 143-164. https://doi.org/10.1177/1038411111400161

[29] Ryff, C.D. (1989) Happiness Is Everything, or Is It? Explorations on the Meaning of Psychological Well-Being. Journal of Personality and Social Psychology, 57, 1069 1081. https://doi.org/10.1037/0022-3514.57.6.1069

[30] Staw, B.M., Sutton, R.I. and Pelled, L.H. (1994) Employee Positive Emotion and Favorable Outcomes at the Workplace. Organization Science, 5, 1-118. https://doi.org/10.1287/orsc.5.1.51

[31] Gist, M.E. and Mitchell, T.R. (1992) Self-Efficacy: A Theoretical Analysis of Its Determinants and Malleability. Academy of Management Review, 17, 183-211. https://doi.org/10.5465/amr.1992.4279530

[32] Grant, A.M. (2007) Relational Job Design and the Motivation to Make a Prosocial Difference. Academy of Management Review, 32, 393-417. https://doi.org/10.5465/amr.2007.24351328

[33] Maslow, A. (1954) Motivation and Personality. Harper \& Brothers, New York. 
[34] Parker, S.K., Williams, H.M. and Turner, N. (2006) Modeling the Antecedents of Proactive Behavior at Work. Journal of Applied Psychology, 91, 636-652. https://doi.org/10.1037/0021-9010.91.3.636

[35] Meyerson, P. and Tryon, W. (2003) Validating Internet Research: A Test of the Psychometric Equivalence of Internet and In-Person Samples. Behavior Research Methods, Instruments, and Computers, 35, 614-620. https://doi.org/10.3758/BF03195541

[36] Brislin, R.W., Lonner, W.J. and Thorndike, R.M. (1973) Cross-Cultural Research Methods. John Wiley and Sons, New York.

[37] Frese, M., Fay, D., Leng, K., Hilburger, T. and Tag, A. (1997) The Concept of Personal Initiative: Operationalization, Reliability and Validity in Two German Samples. Journal of Occupational and Organizational Psychology, 70, 139-161. https://doi.org/10.1111/j.2044-8325.1997.tb00639.x

[38] Kishton, J.M. and Widaman, K.F. (1994) Unidimensional versus Domain Representative Parceling of Questionnaire Items: An Empirical Example. Educational and Psychological Measurement, 54, 757-765. https://doi.org/10.1177/0013164494054003022

[39] Rosseel, Y. (2012) Lavaan: An R Package for Structural Equation Modeling. Journal of Statistical Software, 48, 1-36. https://doi.org/10.18637/jss.v048.i02

[40] R Core Team (2013) R: A Language and Environment for Statistical Computing. Vienna, Austria: R Foundation for Statistical Computing.

https://www.r-project.org/

[41] Aguinis, H., Gottfredson, R.K. and Culpepper, S.A. (2013) Best-Practice Recommendations for Estimating Cross-Level Interaction Effects Using Multilevel Modeling. Journal of Management, 39, 1490-1528. https://doi.org/10.1177/0149206313478188

[42] Milyavskaya, M. and Koestner, R. (2011) Psychological Needs, Motivation, and Well-Being: A Test of Self-Determination Theory Across Multiple Domains. Personality and Individual Differences, 50, 387-391. https://doi.org/10.1016/j.paid.2010.10.029

[43] Burris, E.R., Detert, J.R. and Chiaburu, D.S. (2008) Quitting before Leaving: The Mediating Effects of Psychological Attachment and Detachment on Voice. Journal of Applied Psychology, 93, 912-922. https://doi.org/10.1037/0021-9010.93.4.912

[44] Podsakoff, P.M., MacKenzie, S.B., Lee, J.Y. and Podsakoff, N. P. (2003) Common Method Biases in Behavioral Research: A Critical Review of the Literature and Recommended Remedies. Journal of Applied Psychology, 88, 879-903.

https://doi.org/10.1037/0021-9010.88.5.879 


\section{Appendix}

\section{The Original English Questionnaire Items}

For each of the following statements and/or questions, please circle the point on the scale that you feel is most appropriate in describing you.

1) What is your gender?

O Male

Female

2) What is your highest education?

$\bigcirc$ Middle school and below

$\bigcirc$ High school

Associate degree

$\bigcirc$ Bachelor's degree

Master's degree or above

3) How long have you been working in current company?

$\bigcirc$ Less than 1 year

O 2 - 3 years

○ 4 - 5 years

O 6 - 9 years

More than 10 years

4) How old are you?

Under 18 years old

○ 19 - 29 years old

O 30 - 39 years old

More than 40 years old

\begin{tabular}{|c|c|c|c|c|c|c|c|}
\hline Items & $\begin{array}{c}1 \\
\text { Strongly } \\
\text { Disagree }\end{array}$ & $\begin{array}{c}2 \\
\text { Disagree }\end{array}$ & $\begin{array}{c}3 \\
\text { Slightly } \\
\text { Disagree }\end{array}$ & $\begin{array}{c}4 \\
\text { Undecided }\end{array}$ & $\begin{array}{c}5 \\
\text { Slightly } \\
\text { Agree }\end{array}$ & $\begin{array}{c}6 \\
\text { Agree }\end{array}$ & $\begin{array}{c}7 \\
\text { Strongly } \\
\text { Agree }\end{array}$ \\
\hline I actively attack problems. & 0 & 0 & 0 & 0 & 0 & 0 & 0 \\
\hline $\begin{array}{l}\text { Whenever something goes } \\
\text { wrong, I search for a } \\
\text { solution immediately. }\end{array}$ & 0 & 0 & 0 & 0 & 0 & 0 & 0 \\
\hline $\begin{array}{l}\text { Whenever there is a chance to } \\
\text { get actively involved, I take it. }\end{array}$ & 0 & 0 & 0 & 0 & 0 & 0 & 0 \\
\hline $\begin{array}{l}\text { I take initiative immediately } \\
\text { even when others don't. }\end{array}$ & 0 & 0 & 0 & 0 & 0 & 0 & 0 \\
\hline $\begin{array}{l}\text { I use opportunities quickly } \\
\text { in order to attain my goals. }\end{array}$ & 0 & 0 & 0 & 0 & 0 & 0 & 0 \\
\hline $\begin{array}{l}\text { Usually I do more than } \\
\text { I am asked to do. }\end{array}$ & 0 & 0 & 0 & 0 & 0 & 0 & 0 \\
\hline $\begin{array}{l}\text { I am particularly } \\
\text { good at realizing ideas. }\end{array}$ & O & 0 & 0 & 0 & 0 & 0 & 0 \\
\hline $\begin{array}{l}\text { If you look at your job as } \\
\text { a whole: How many } \\
\text { own decisions does it } \\
\text { allow you to make? }\end{array}$ & $\mathrm{O}$ & 0 & 0 & $\mathrm{O}$ & $\mathrm{O}$ & 0 & 0 \\
\hline
\end{tabular}




\section{Continued}

\begin{tabular}{|c|c|c|c|c|c|c|c|}
\hline $\begin{array}{c}\text { Can you determine } \\
\text { how you do your work? }\end{array}$ & 0 & 0 & 0 & 0 & 0 & 0 & 0 \\
\hline $\begin{array}{l}\text { Can you plan and arrange } \\
\text { your work on your own } \\
\text { (e.g., calculate, which } \\
\text { material/tools you need)? }\end{array}$ & 0 & 0 & 0 & 0 & 0 & 0 & 0 \\
\hline $\begin{array}{l}\text { How much can you } \\
\text { participate in decisions of } \\
\text { your superior (e.g., the } \\
\text { superior asks you for } \\
\text { your opinion and } \\
\text { asks for suggestions)? }\end{array}$ & 0 & 0 & 0 & 0 & 0 & 0 & 0 \\
\hline $\begin{array}{l}\text { Overall, I think being a } \\
\text { nurse fulfills an important } \\
\text { purpose in my work life. }\end{array}$ & 0 & 0 & 0 & 0 & 0 & 0 & 0 \\
\hline $\begin{array}{l}\text { Overall, I get enough } \\
\text { time in nursing to } \\
\text { reflect on what I do at work. }\end{array}$ & 0 & 0 & 0 & 0 & 0 & 0 & 0 \\
\hline $\begin{array}{l}\text { Overall I think I am } \\
\text { reasonably satisfied } \\
\text { with my work life. }\end{array}$ & 0 & 0 & 0 & 0 & 0 & 0 & 0 \\
\hline $\begin{array}{l}\text { Overall, most days I feel } \\
\text { a sense of accomplishment } \\
\text { in what I do in nursing. }\end{array}$ & 0 & 0 & 0 & 0 & 0 & 0 & 0 \\
\hline
\end{tabular}

